\title{
Enhancing the Ecological Value of Sea Dikes
}

\author{
Babette Scheres *(i) and Holger Schüttrumpf $(\mathbb{D}$ \\ Institute of Hydraulic Engineering and Water Resources Management, RWTH Aachen University, \\ Mies-van-der-Rohe-Straße 17, 52056 Aachen, Germany \\ * Correspondence: scheres@iww.rwth-aachen.de
}

Received: 9 July 2019; Accepted: 31 July 2019; Published: 5 August 2019

check for updates

\begin{abstract}
Sea dikes protect low-lying hinterlands along many coasts all around the world. Commonly, they are designed as embankments with grass covers or grey revetments accounting for the prevailing hydraulic loads. So far, incorporation of ecological aspects in the dike design is limited. With regard to increasing environmental awareness and climate change adaptation needs, the present study reviews methods for ecological enhancement of sea dikes and discusses limitations and challenges related to these methods. In doing so, one key aspect is to maintain dike safety while increasing the ecological value. Potential for ecological enhancement of sea dikes has been found regarding natural or nature-based solutions in the foreshore, dike surface protection measures (vegetated dike covers, hard revetments and dike roads) and the dike geometry. While natural and nature-based solutions in the foreland are investigated thoroughly, so far only few experiences with ecological enhancements of the dike structure itself were gained resulting in uncertainties and knowledge gaps concerning the implementation and efficiency. Additional to technical uncertainties, engineers and ecologists meet the challenge of interdisciplinary collaboration under consideration of societal needs and expectations.
\end{abstract}

Keywords: green sea dikes; ecological enhancement; ecological engineering; nature-based solutions; ecosystem services

\section{Introduction}

Dikes, an integrated part of flood defense systems, have proven worldwide as effective protection against fluvial and coastal flooding. The dike form and alignment, building materials and associated structures vary depending on the boundary conditions, such as hydraulic loads, spatial restrictions and locally available materials. Commonly, dikes consist of an earth-filled core made of granular or cohesive soil materials with a grass cover as surface protection [1].

In Germany alone, around $1200 \mathrm{~km}$ of sea dikes and estuarine dikes protect an area of more than $12,000 \mathrm{~km}^{2}$ and a population of more than 2,400,000 people [2]. Historical documentations give insight into continuous dike heightening and strengthening efforts after extreme storm surge events in the past $[2,3]$. Nowadays, sea dikes and revetments are designed and constructed according to the available guidelines for coastal structures, e.g., The International Levee Handbook [1], under consideration of hydraulic aspects, such as the design water level and design wave parameters, as well as geotechnical aspects, e.g., soil properties. So far, ecological aspects are not directly incorporated in dike design.

In times of climate change and growing awareness of environmental issues [4], increased design requirements and new adaptation strategies for coastal structures become necessary to account for increased loads on the one hand and nature conservation on the other hand [5-7]. Latest developments in coastal engineering integrate the utilization of ecosystem services and natural processes in engineering practice for more sustainable and adaptive design. Thereby, a wide range of new engineering disciplines, such as ecosystem-based engineering and building with nature, have been developed [8]. 
However, no integrated concept for ecologically valuable dikes is available so far. Dikes are conventionally built as hard engineering structures that withstand the forces of wind, waves and flooding, whereby constituting an interference with nature $[9,10]$. Standard seeding mixtures that consist of different grasses and a small percentage of herbs are known to ensure the main functions of the grass cover-protection against mechanical forces, such as wave impact, and influences of weather [11]—whereas ecological aspects are not considered sufficiently. Sites with higher hydraulic loads are usually equipped with grey revetments that directly impact the ecological connectivity $[12,13]$.

Nevertheless, there is potential to make use of ecosystem services and enhance the ecological value of dike systems. Fundamental knowledge, e.g., on the erosion resistance of vegetated dike covers, has been gained and various methods applicable for enhancing the ecological value of dikes, such as vegetated revetments, have been developed. With reference to [14], the main objective is now to develop an integrated design concept for ecologically valuable dikes. In doing so, the aim of this review is

- to outline methods and approaches applicable to increase the ecological value of dikes,

- to show potentials, challenges and open research questions and

- to discuss the conception of ecologically valuable sea dike systems with regard to ecology, engineering and society.

First the ecological basics are explained and existing frameworks for integrating ecosystems in coastal engineering are summarized. Subsequently, components of sea dike design with potential for ecological enhancement are presented regarding their relevance for dike design and ecological aspects. Furthermore, existing dike reinforcement methods that are worth considering for ecologically valuable sea dikes are described. Finally, the conception and implementation of ecologically valuable sea dike systems under consideration of ecology, engineering and society are discussed.

\section{Ecological Basics}

\subsection{Ecosystem Engineers}

Ecosystem engineers are organisms that affect biotic and/or abiotic conditions by direct or indirect structural changes in the form of modification, maintenance or creation of habitats and thereby modulate the physical conditions and availability of resources to other species. Autogenic ecosystem engineers, such as corals or grasses, cause structural changes due to their physical existence alone. Allogenic ecosystem engineers, such as beavers or plants that affect the subsoil due to root growth, modify their environment due to direct structural changes $[15,16]$.

\subsection{Ecosystem Services}

Ecosystems are defined as functional systems consisting "of all the organisms and the abiotic pools with which they interact" [17]. Benefits provided to people by ecosystems are so-called ecosystem services. According to the Millennium Ecosystem Assessment [18], these ecosystem services can be categorized into

- $\quad$ provisioning services (food, fiber, fuel, water, ... )

- regulating services (air quality regulation, climate regulation, water regulation, ... )

- $\quad$ supporting services (nutrient cycling, soil formation, photosynthesis, ... )

- cultural services (cultural diversity, education, aesthetics, ... )

Changes in ecosystems, which in turn lead to changes in ecosystem services, directly influence human well-being. Then again, human activities may cause changes in ecosystems, resulting in changes in ecosystem services and finally human well-being. Therefore, the assessment of ecosystem services has become a valuable planning and management tool [18-20]. 
Organisms of major importance in estuaries and coasts are dune plants, tidal marsh plants, mangroves, seagrasses, kelp and seaweeds, corals, reef-forming bivalves, burrowing crustaceans and infauna. Their effects on structural, abiotic and biotic factors are discussed in detail in [21]. Typical coastal protection ecosystem services provided by the resulting ecosystems (coral reefs, salt marshes, mangrove forests, etc.) are the attenuation and/or dissipation of waves, sediment retention and/or stabilization and the reduction of flooding and spray [22]. The use of ecosystems for coastal protection has attracted great interest in recent years [10,23-25].

\subsection{Existing Frameworks for Integrating Ecosystems in Coastal Engineering}

Various frameworks, namely building with nature [26,27], engineering with nature [28], living shorelines [29], etc. exist that deal with the integration or use of ecosystems for coastal protection purposes. While the concepts may differ in their focus, a common objective is to make use of ecosystem services and/or natural processes for ecological, economic and social benefits in relation to hydraulic engineering [8].

In general, nature-based coastal engineering approaches can be distinguished in (1) the systematic utilization of ecosystem engineers to initiate structural changes that finally result in coastal protection ecosystem services and (2) the adaption of conventional coastal structures with the aim to increase their ecological value [30]. Additionally, the framework building with nature pursues the principle of actively using not only nature's resources but also nature's dynamics for hydraulic engineering questions [26,27]. In general, using nature's engineers can be realized by restoring/maintaining ecosystems, integrating ecosystem engineers in new environments or imitating ecosystem engineers without direct use of the organisms [21].

One way of categorizing nature-based solutions is to distinguish between "fully natural solutions", "managed natural solutions", "hybrid solutions that combine structural engineering with natural features" and "environment-friendly' structural engineering" ([31], similar categorization in [32]). To date, guidelines for the design, implementation, monitoring and maintenance of nature-based coastal engineering solutions are limited [31].

\section{Sea Dike Design Aspects with Potential for Ecological Enhancement}

The main function of sea dikes is to protect the hinterland from flooding. Therefore, dike safety has the highest priority in dike design. The dike must be able to withstand waves, currents and high water without failure due to erosion or insufficient dike stability while building a barrier between land and water. Environmental aspects are considered during dike design, e.g., aiming at minimizing/compensating environmental impacts and optimizing resources use [1,11], however the ecological value of the dike system itself is generally of secondary relevance. In the following, various components of sea dike design that allow for ecological enhancements of the dike system are presented regarding their relevance for dike design and ecological aspects. First the vicinity of the dike, i.e., the foreland, and subsequently the dike structure itself including slope inclination, dike roads, dike revetments and dike vegetation are explored.

\subsection{Foreshore Vegetation and Fauna}

Foreshore vegetation and fauna influence the ecological value of the coastal system and affect hydrodynamics and morphology. Comprehensive reviews on coastal ecosystems and their ecosystem services in terms of coastal protection and co-benefits are given e.g., in [21-23]. The main coastal protection services observed are (1) the attenuation of waves and (2) the stabilization of the shoreline and (3) accretion of sediments. Wave attenuation is ascribed to wave breaking due to water depth change (e.g., reefs) and wave damping due to increased bottom friction (e.g., mangroves or marshes) [24]. Sediment deposition is promoted due to reduced flow velocity and sediment binding by plant roots [21,22]. Moreover, soil accretion can be increased through the accumulation of organic matter produced by ecosystems, e.g., for marshes and mangroves [33]. 
Mangroves, salt marshes and sea grass show wave damping capacities that depend on vegetation properties, e.g., the vegetation height and width, and hydraulic conditions, e.g., the water depth [34-37]. Additionally, increased sediment accretion was observed for these foreshore vegetations [38-40]. Likewise, wave attenuation [41,42] and sediment trapping capacities $[43,44]$ were documented for coral and oyster/mussel reefs. A recently published meta-analysis performed by Narayan et al. [24] shows average wave height reductions of $72 \%$ for salt-marshes and $70 \%$ for coral reefs followed by average wave height reductions of $36 \%$ for seagrass and $31 \%$ for mangroves. As average values for water depths and wave heights were used within this study, further analyses for extreme events are required to consider design cases. Carbon sequestration, water purification and habitat creation are valuable co-benefits provided by foreshore vegetation and fauna [21,22].

Due to spatial and temporal variation in ecosystems and not yet resolved knowledge gaps, integration of coastal protection services of ecosystems in design processes still poses a challenge [45,46]. However, combining hard coastal structures with foreshore ecosystems can decrease the hydrodynamic loads on the built infrastructure, thus increasing the design life and reducing necessary maintenance efforts $[8,37,47]$.

\subsection{Slope Inclination}

While the dike height is determined based on the hydraulic boundary conditions (design water level and wave run-up), the dike slopes are designed as a compromise between optimal dike stability (mild slopes) and minimal material consumption and dike footprint (steep slopes) [1].

Using wide green dikes with a grass covered shallow seaward slope around 1:7 is assumed to have positive effects on nature, recreation and tourism compared to a standard sea dike with a steeper slope (around 1:3) and grey revetment [6]. However, as the dike footprint increases linearly with the slope inclination, the loss of original habitat increases accordingly [48]. At the same time altered habitat is created (e.g., grass meadows, see [6]), which may have an ecological value. Effects on coastal processes, such as reflection at the structure [48], are reduced with milder slopes.

\subsection{Dike Roads}

Roads on dikes are a crucial element for dike inspection, maintenance and defense purposes. Commonly, dike roads are built as asphalt-paved roads along the dike crest or the inner dike berm (above mean high water) with regular access from the hinterland via ramps. The dimension, foundation and materials of these dike roads have to enable crossing of heavy vehicles $[1,11]$.

As a more natural alternative to asphalt-paved roads, vegetated geocellular containment systems (see Section 4.2.3 for further details) were used on the crest of a river dike in Germany [49]. Tests with similar soils showed that the traffic security was given even under extreme conditions [49].

\subsection{Dike Revetments}

If boundary conditions do not permit the use of grass covers for erosion protection, e.g., in the case of high hydraulic loads, hard revetments, such as rip-rap or placed block revetments, are necessary [1]. Design of hard revetments depends on the revetment type and its features, e.g., interlocking vs. no interlocking blocks and permeable vs. impermeable revetments. Design guidance is given e.g., in the Rock Manual [50] and the International Levee Handbook [1].

Vegetated or colonized revetments pose a possibility to increase the ecological value of grey revetments (Figure 1). However, yet little information exists on the ecological effectiveness and other positive or negative side effects of vegetating or colonizing revetments.

Along inland waterways, the use of grouted revetments filled with flowable topsoil and alginate was tested for establishment of vegetation and colonization of fauna within the cavities of the revetment [51]. In case of fully-grouted revetments, the colonization can be supported by using a loose rip-rap on top of the grouted revetment [52]. Similarly, concrete mats-double-layer interconnected geotextile mats filled with flowable concrete-can be covered with a vegetated topsoil 
that acts as sacrificial layer and only serves ecological and aesthetic purposes [53]. Fully vegetated grouted revetments and concrete mats are pictured [52,53], though no deeper ecological analyses were conducted.

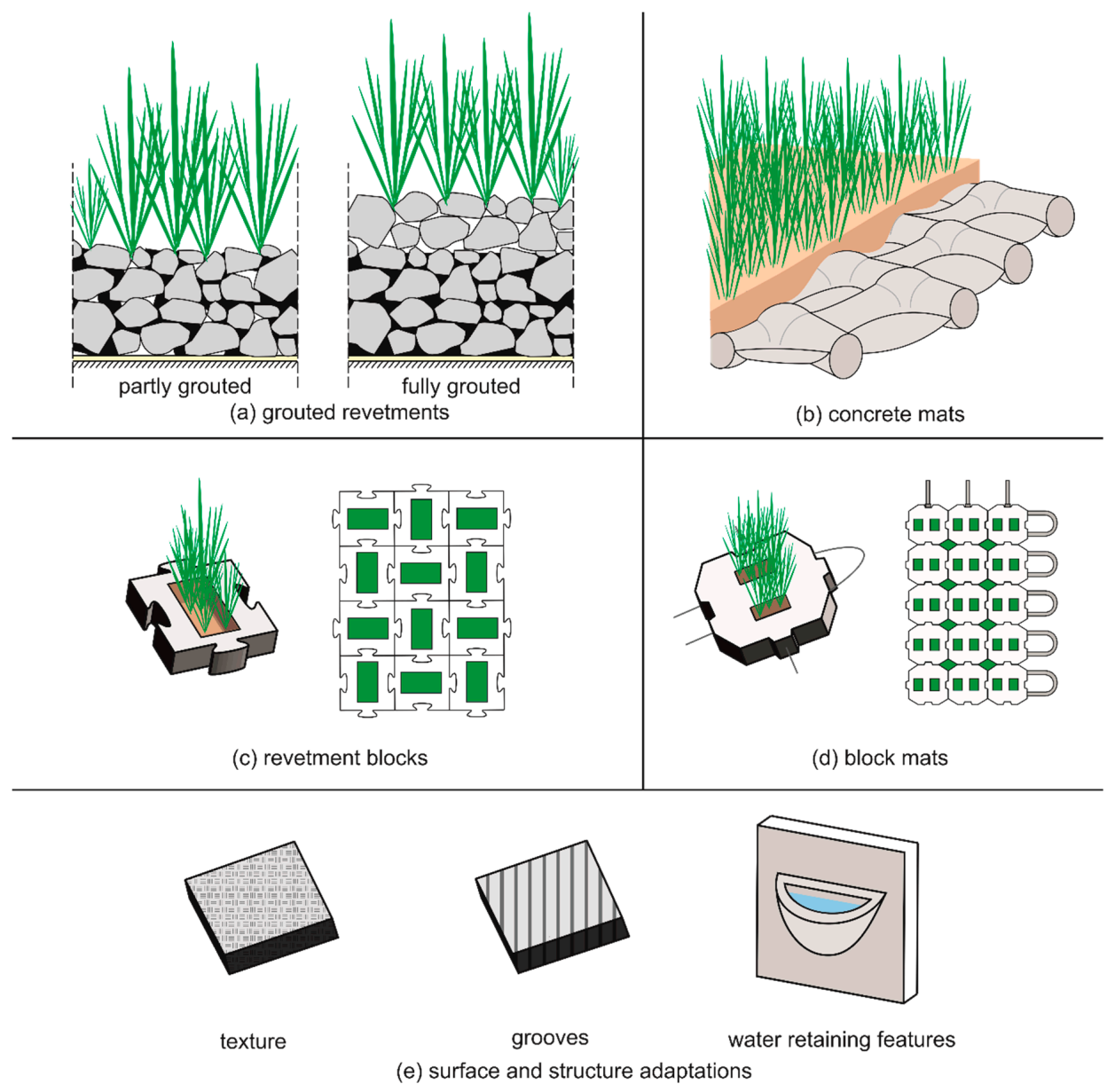

Figure 1. Vegetated and/or colonized revetments. (a) Vegetated grouted revetments after [52], (b) vegetated concrete mats after [53], (c) vegetated revetment blocks after [55], (d) vegetated block mats after [54] and (e) further surface and structure adaptations to promote colonization after [56-58].

With reduced sealed area, special concrete revetment blocks and block mats allow for vegetation of the revetment. Here, openings between the single blocks and open areas within the blocks enable the establishment of vegetation [54]. For further support of vegetation growth, concrete revetment blocks can be combined with geotextiles [55]. Increased stabilization of the revetment blocks is anticipated as the roots anchor the blocks with the underground soil [55]. Vegetation establishment is assumed to depend amongst others on the dimension of the opening. Open cell block mats presented by [54] have an open area of $20 \%$, revetment blocks in [55] an open area of $25 \%$.

Colonization of organisms, such as algae or mussels, can be supported by adapting the surface or general structure of revetments. Here, a range of small (e.g., texture and small grooves) to larger adaptations (e.g., water retaining features or elevations) is possible [56-58]. Measures have to be chosen with regard to the flooding frequency/tidal elevation and target organisms [58]. Water retaining features were found as most effective measure for increasing the number of sessile and benthic species, followed by intertidal pits for benthic species [58]. Detailed results of a meta-analysis on the effectiveness of the various measures on the abundance and number of organisms (sessile, mobile, benthic, fish and habitat-forming taxa) under consideration of the environmental settings (intertidal, subtidal) are given in [58]. When supporting the colonization of organisms on hard substrates, the species origin (native, 
non-native, cryptogenic) and possible negative effects of the newly evolving ecosystem have to be considered $[59,60]$.

\subsection{Grass and Herbaceous Dike Covers}

\subsubsection{Practical Relevance and Current Practice}

Dense grass covers have proven worldwide as simple, effective and simultaneously sustainable surface protection against erosion on dikes $[1,11,61,62]$. Besides functioning as surface protection, grass covers can have an ecological value and can increase the aesthetic appeal [1].

While the aboveground part of grass covers-the sward and the stubble-absorbs rainfall energy and can increase surface roughness and thereby protects against splash and interrill erosion, reduces hydrodynamic loads and catches sediments, the underground part-the roots-binds soil particles and modifies physical and chemical soil parameters and thereby affects infiltration, reinforces the soil and protects against rill and gully erosion [63-66], cf. Figure 2.

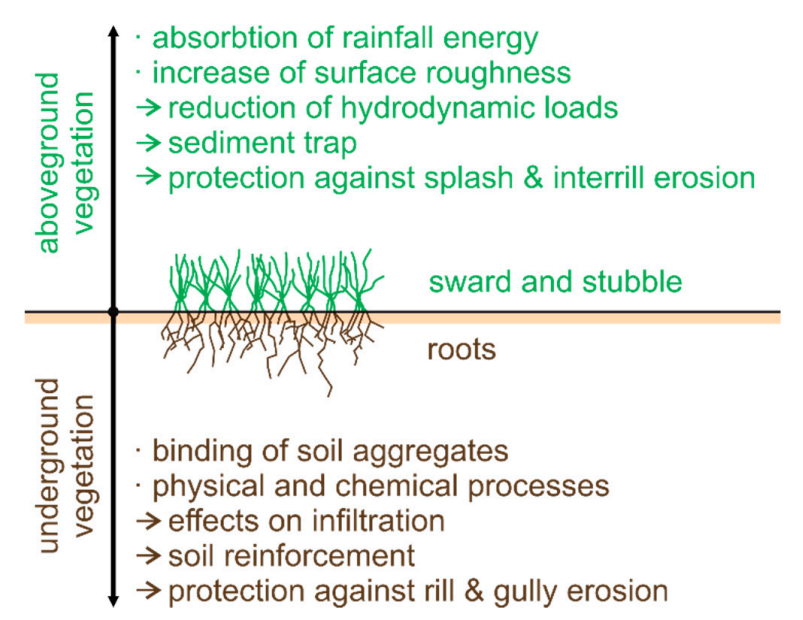

Figure 2. Structure and physical effects of a grass cover.

The grass species applied for dike covers have to be selected according to the local climate, soil and hydraulic conditions and should ideally correspond to native species $[1,62]$. To provide an erosion-resistant dike cover, the following requirements have to be fulfilled: (1) permanently green, dense grass cover with different root forms and depths, (2) combination of fast and slow germinating species, (3) adjusted to boundary conditions, e.g., salt tolerance or frost resistance, and (4) tolerance to cutting, step-resistance and regenerative capacity $[11,67,68]$. The optimal species composition is defined as a combination of $70 \%$ tussock-forming grasses, $15 \%$ of species with subterraneous runners and $15 \%$ with rhizomes [69]. The network of horizontally creeping roots lying within the upper 15-20 cm results in strengthening of the soil structure while deep-reaching roots anchor the upper with the lower soil layers [70]. In Germany, standard seeding mixtures consisting of different grasses (perennial ryegrass, smooth meadow-grass and red fescue) and, if desired, a small percentage of herbs (yarrow) are recommended for sea dike vegetation [11]. Ryegrass provides a fast development of the grass cover, although insufficient root volume; fescues and meadow grasses lead to deep, fine roots and increase the erosion resistance significantly [71]. In tropical and Mediterranean regions, often vetiver grass is used for slope stabilization [72,73].

\subsubsection{Erosion Resistance Against Overflow and Wave Overtopping}

The erosion resistance of green dike covers has been investigated in wave flumes, within in-situ tests on real dikes and with model tests on artificial research dikes or dike covers. For full-scale model tests in wave flumes, natural grass sods were excavated and installed onto the dike model [74,75]. 
With the Dutch wave overtopping simulator (Dutch WOS) erosion tests on real dikes were made possible [76-79]. Investigations on artificial research dikes [80] and tests on top layers in planter trays with the fixed US wave overtopping simulator (US WOS) [81,82] complete the portfolio of overflow and wave overtopping erosion tests on vegetated dikes. Table A1 summarizes the conducted investigations, tested objects, applied loads and corresponding results.

While design guidance conservatively recommends tolerable overtopping discharges of $5 \mathrm{l} /(\mathrm{sm})$ with significant wave heights of $\mathrm{H}_{\mathrm{m} 0}=1-3 \mathrm{~m}$ for maintained and closed grass covers [83], physical model tests and in-situ analyses show that a good grass cover is generally able to resist mean wave overtopping discharges up to $30 \mathrm{l} /(\mathrm{sm})$ or higher $[75,76,78,82]$. Weak points, such as rabbit holes, trees or poor grass condition, reduce the erosion resistance drastically $[78,79,82]$.

Often only little information on the tested dike vegetation is given and test results cannot be generalized or transferred to other boundary conditions (vegetation type, grass condition, etc.). Though, by considering the duration of loading and quantitative vegetation parameters within the erosion analyses, a linear correlation between the cumulative overtopping volume $V_{\text {total }}$ at failure and the product of root volume and root length was found [82]. Meanwhile, meta-data analyses on the soil resistance against concentrated flows revealed an exponential decrease in soil detachment ratios due to rill and gully erosion with increasing root density and root length density $[64,65]$.

\subsubsection{Erosion Resistance Against Wave Impacts}

Grass covers on the seaward slope can be affected by wave impacts. No damages have to be expected for waves up to $0.75 \mathrm{~m}$ height for grass covers of good quality [66]. Weak spots, such as mice holes or dead plants, induce earlier erosion [75]. For grass sods with initial damage, a threshold wave height of $0.5 \mathrm{~m}$ is concluded, beyond which erosion starts [84]. Cracks, especially water filled cracks, increase the risk of greater damage due to wave impacts [85]. Generally, erosion due to wave impacts is influenced by the homogeneity and quality of the clay and grass, sand inclusions and weak points [84]. Detailed investigations, e.g., on the correlation of vegetation traits and wave impact resistance, are lacking.

\subsubsection{Influence of Maintenance}

Species diversity, vegetation coverage and root density on sea dikes strongly depend on the maintenance measures applied $[66,86]$. Species-rich communities were generally found in unfertilized areas. At the same time, highest erosion resistances were found for long-term unfertilized dikes [66]. Laboratory studies confirmed that erosion resistance increases with increasing species diversity [87]. Consequently, maintenance measures directly affect soil erodibility. Cessation of fertilization increases species-richness, root length, root weight and thus erosion resistance already after a short time [86].

\subsection{Woody Vegetation on Dikes}

Generally, dense well-maintained grass covers are recommended for dike vegetation [1]. However, as a result of natural progression or intended promotion, occasionally woody vegetation in the form of forest-like stocks, tree rows or solitary trees can be found on dikes [88]. Woody vegetation differs substantially from grasses and herbaceous vegetation or shrubs by their surface (stem and crown) and underground structure (root system). Thus, woody vegetation results in different biomechanical effects than grasses or herbaceous vegetation. According to [63], woody vegetation improves in particular mass stability due to deeper and stronger roots, while grasses and herbs provide especially increased surface erosion protection due to the dense ground cover.

The use of woody vegetation on dikes is widely debated. While woody vegetation offers ecological functions, e.g., providing habitats, balancing water quality and temperature, as well as cultural, recreational and aesthetic functions [89], the effects on dike safety are contrarily discussed. Table 1 summarizes reasons for and against woody vegetation on dikes. While established recommendations and guidelines vary from prohibiting woody vegetation on dikes as a general rule (e.g., $[62,90])$, 
exceptions can be possible as long as the stability and functionality of the dike is not restricted or the risks are acceptable [91]. Adaptation measures for dikes with woody vegetation, such as dike oversizing, structurally effective sealings or securing of trees, represent options to ensure the structural safety $[91,92]$.

Table 1. Reasons for and against woody vegetation on dikes.

\begin{tabular}{lc}
\hline \multicolumn{1}{c}{ Contra } & Reference \\
\hline $\begin{array}{lc}\text { Increased risk of vegetation-induced dike damage, e.g., holes due to tree failure, damage of } \\
\text { dike sealing }\end{array}$ & {$[1,89,93,94]$} \\
\hline $\begin{array}{lc}\text { Increased risk of erosion: trees as starting point for external erosion (flow concentrations, } \\
\text { turbulences), increased internal erosion due to cavities as a result of root decay }\end{array}$ & {$[1,63,89,93,94]$} \\
\hline Additional forces, e.g., wind forces, transmitted into slope & {$[1,63,93]$} \\
\hline Hinder the development of an erosion-resistant surface cover due to shadowing & {$[1,93]$} \\
\hline $\begin{array}{lc}\text { Effects on water flow: reduction of flow velocities through increased roughness, reduced } \\
\text { flow cross section }\end{array}$ & {$[63,89]$} \\
\hline Increased risk to attract burrowing animals & {$[1,93]$} \\
\hline Complication of monitoring and maintenance & {$[1,63,89,93]$} \\
\hline Obstacles during flood fighting operations & {$[1,63,93]$} \\
\hline \multicolumn{1}{c}{ Pro } & Reference \\
\hline Increased soil stabilization due to root reinforcement & {$[1,63,89,95,96]$} \\
\hline Increased (global) dike stability due to additional weight and/or deeper roots & {$[63,94,95,97]$} \\
\hline Positive effects on soil moisture due to interception, water extraction and transpiration & {$[63,89,94]$} \\
\hline Foreshore woody vegetation and woody vegetation on the outer slope can act as & {$[88,94,97]$} \\
\hline breakwater or protection against ice drift and reduce flow velocities & {$[89]$} \\
\hline Positive effects on sediment transport & {$[89,98]$} \\
\hline Ecological functions, e.g., providing habitats, balancing water quality, temperature etc. & {$[89,95,98]$} \\
\hline Cultural, recreational and aesthetic functions & {$[95,97]$} \\
\hline Reduced maintenance costs/efforts & \\
\hline
\end{tabular}

\section{Reinforcement Methods for Sea Dikes}

To adapt to increasing design parameters or also to compensate for reduced dike resistance, e.g., in the case of lower erosion resistance of ecologically valuable sea dike vegetation, reinforcement measures might be worth considering. In the following, an overview on dike reinforcement methods (Section 4.1) and a detailed comparison of the various grass reinforcement methods (Section 4.2) are given.

\subsection{Overview}

Commonly, sea dikes consist of a sand core and a clay layer as sealing dike cover [1,11]. Latest innovations, however, show alternative dike designs with further dike strengthening potential, such as dike core reinforcements and new methods for dike sealing.

Studies on the use of geotextiles in the form of geotextile loops, horizontal and slope-parallel geotextile layers and geotextile tubes to increase dike safety against wave overtopping are reported by [99]. Testing the first three methods, wrapped loops and slope-parallel nail-anchored geotextiles (for slopes $\geq 1: 2.5$ ) prove to be stable constructions with limited deformations [99]. Integrated continuous geotextile soil-filled tubes were found to offer an erosion resistant, stable dike core [100].

In case of reinforcement needs for existing dikes at limited space conditions, measures are necessary that do not increase the dike footprint further. Here sheet piles and concrete screens in the crestline or dike nailing and mixed-in-place columns along the landward slope are possible. Sheet piles 
and concrete screens in the crestline improve the stability of the dike and help controlling seepage $[1,6]$. In case of an overflow or overtopping event and consequent erosion of the landside slope, the height of the dike and with this the flood protection function are still ensured when applying sheet piles [101].

Dike nailing, a modification of the traditional soil nailing, represents a cost-effective measure with which dike stability is improved due to increased structural integrity and increased shearing resistance [102,103]. A similar effect is given with the mixed-in-place method with which dike stability is increased due to columns of soil mixed with cement [6].

As an alternative to the valuable mineral clay sealing, geosynthetic clay liners can provide dike sealing and prevent from typical dike breaches [104]. Grass reinforcements represent another dike reinforcement method, which is described in detail in the following chapter.

Generally, alternative dike designs are associated with additional costs for material, machinery, etc. When assessing the cost-efficiency, resulting benefits, such as reduced necessary dike height or footprint, better adaptation to local conditions and social or ecological benefits, have to be considered.

\subsection{Grass Reinforcement}

As hydraulic loads exceed the strength of the natural grass cover, artificial grass reinforcement can be a possible solution to avoid dike failure and preserve the natural cover. Amongst others, erosion control meshes and blankets, fiber roving systems, turf reinforcement mats (TRM) and vegetated geocellular containment systems can serve as erosion control measures by reinforcing the cover layer [105]. In the following, an overview on selected up-to-date grass reinforcement methods and their resistance is given.

\subsubsection{Smart Grass Reinforcement (SGR)}

The concept of SGR uses a thin, three-dimensional geogrid that is placed underneath the grass surface by cutting and lifting the upper layer of the existing grass cover, installing the geogrid onto the underground and finally putting the grass layer on top of the geogrid. After regeneration of the grass cover, the intertwining of roots and geogrid leads to an increased erosion resistance and the geogrid itself provides a protective function against erosion of the underlying soil. Tests with the Dutch wave overtopping simulator [106] on a real dike section with a grass cover in poor condition showed no major erosion for mean overtopping rates of $50 \mathrm{l} /(\mathrm{sm})$ over a $6 \mathrm{~h}$ testing period at the reference (unreinforced) and reinforced dike section. After initiating artificial damage in the form of holes, attached poles, etc., the additional erosion resistance due to SGR became apparent with less progressive erosion compared to the unreinforced dike section [107,108].

\subsubsection{High Performance Turf Reinforcement Mats (HPTRM)}

HPTRMs are three-dimensional, durable geotextile mats that are installed onto the underground and covered by grass seeds and a thin layer of soil. After roots have grown through the geotextile, an intertwined system with increased erosion resistance is formed. Thereby HPTRMs enhance the seed germination and vegetation growth through modifying the local micro climate.

Information on material properties (weight per unit area, tensile strength, etc.) and performance (erosion resistance due to overflow and ability to encourage seed germination and plant growth) were achieved from standardized tests of the National Transportation Product Evaluation Program (NTPEP). For example, maximum permissible flow velocities of $7.6 \mathrm{~m} / \mathrm{s}$ for vegetated HPTRMs $[109,110]$ and $3.8 \mathrm{~m} / \mathrm{s}$ for unvegetated HPTRMs [110] were obtained while assessing the performance in protecting earthen channels from stormwater-induced erosion [111]. Tests on seed germination and plant growth showed biomass improvement of exemplarily $378 \%$ [110].

Tests at the Colorado Wave Overtopping Facility have shown no damage after $6 \mathrm{~h}$ testing of dormant HPTRM-reinforced Bermuda grass with maximum mean overtopping discharges of $370 \mathrm{l} /(\mathrm{sm})$. Referred to the cumulative overtopping volume, the erosion resistance of HPRTM-reinforced grass covers against wave overtopping is found to be at least 2.8 times higher compared to unreinforced 
grass covers [81]. After erosion of the top soil layer, the HPTRM still provides further protection against erosion and thereby increases the overall erosion resistance of the system [112,113].

\subsubsection{Geocellular Containment Systems}

Geocellular containment systems, i.e., three-dimensional geotextiles in the form of honeycombed cells connected to each other and filled with substrate, show an increased carrying capacity and improved deformation behavior due to the activation of passive earth resistance and tensile ring forces. Critical flow velocities are increased as erosion forces are absorbed by the network of cells and soil and the soil is hold within the cells [49,114]. Design velocities of $0.9 \mathrm{~m} / \mathrm{s}$ for geocells filled with unvegetated topsoil and $1.5 \mathrm{~m} / \mathrm{s}$ for geocells filled with vegetated topsoil are recommended [115].

\subsubsection{Comparative Analysis}

Figure 3 summarizes the results of erosion tests and recommendations for design velocities of the SGR system, HPTRMs, ECRMs (Erosion Control Revegetation Mats) and geocellular containment systems. The SGR system and HPTMR-strengthened grass covers withstand maximum possible average overtopping discharges far beyond the commonly indicated $5 \mathrm{l} /(\mathrm{sm})$ for preventing dike damage [83]. Still, the actual resistance is unknown as existing testing facilities lack of sufficiently high hydraulic power $[81,107,112,113]$. Compared to the design velocities for grass-only [116], the design velocities for vegetated geocells [105] seem to be very conservative and further research is required. Grass reinforcement with geotextiles has proven to be effective and feasible for sloped structures. However, the obtained testing results are only applicable to similar systems, i.e., similar geotextile, grass species and substrate.

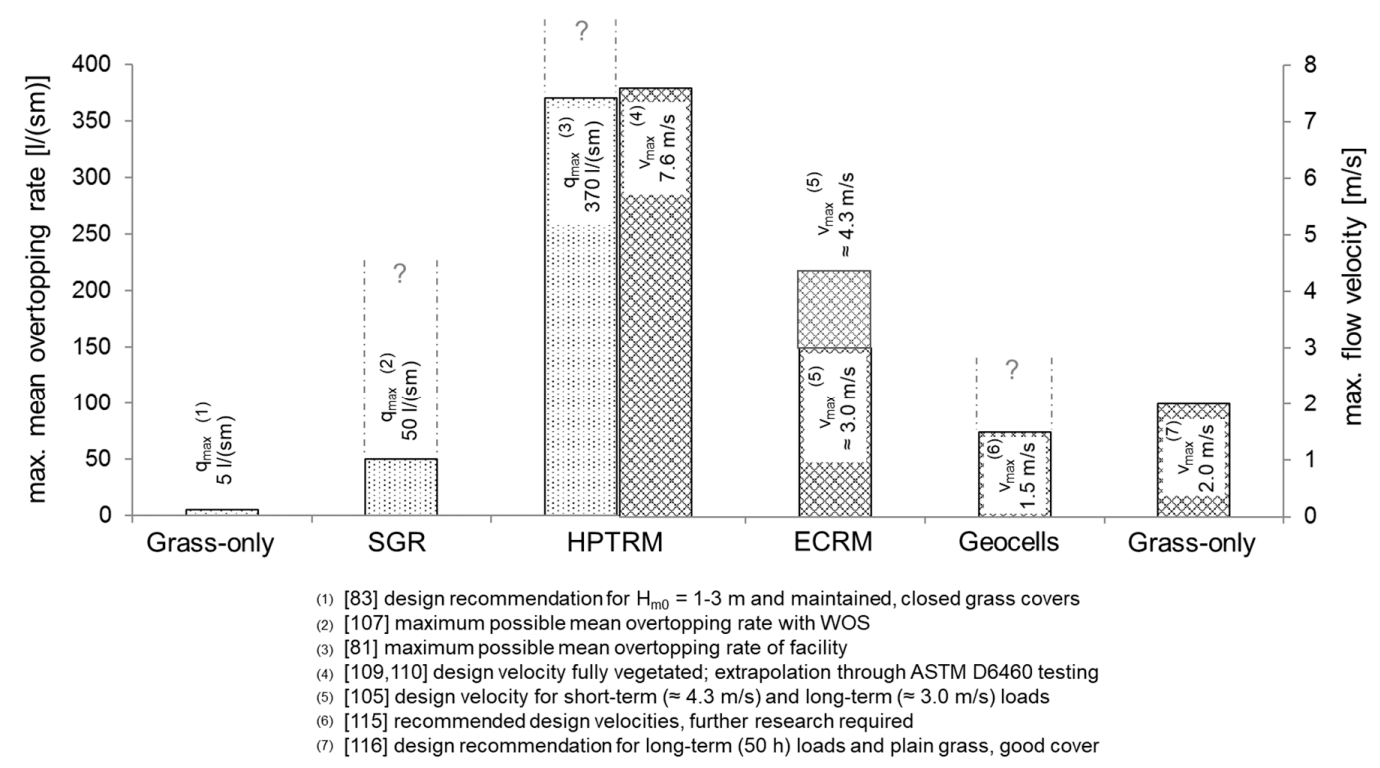

Figure 3. Maximum mean overtopping rates and maximum flow velocities for the Smart Grass Reinforcement system (SGR), High Performance Turf Reinforcement Mats (HPTRMs), Erosion Control Revegetation Mats (ECRMs) and geocellular containment systems from literature.

\section{Discussion}

\subsection{Technical and Functional Conception of Ecologically Valuable Sea Dikes}

Coastal protection is the main function of sea dikes. Therefore, dike safety is the key factor during the design process. Developing an integrated design concept for ecologically valuable sea dikes, the ecological value of the system has to be enhanced while maintaining the dike safety. Table 2 summarizes methods for ecological enhancement of dikes and their limitations/challenges. Based on 
the findings of the present review, potential for ecological enhancement of sea dikes has been found regarding the foreshore composition, dike surface protection measures (vegetated dike covers, hard revetments and dike roads) and the slope inclination. A schematic sketch of a sea dike system with nature-based solutions is given in [32].

Table 2. Summary of methods for ecological enhancement of dikes and their limits/challenges.

\begin{tabular}{llll}
\hline Dike Component & Common Design & Ecological Enhancement & Limitations/Challenges \\
\hline Foreshore & $\begin{array}{l}\text { Not directly integrated in } \\
\text { dike design }\end{array}$ & $\begin{array}{l}\text { Ecosystem engineering } \\
\text { (marshes, reefs, etc.) or } \\
\text { nature-based solutions } \\
\text { (e.g., artificial reefs) }\end{array}$ & $\begin{array}{l}\text { Little experience concerning } \\
\text { establishment and management. } \\
\text { Uncertainties concerning (constant) } \\
\text { coastal protection function }\end{array}$ \\
\hline Slope inclination & $\begin{array}{l}\text { Slope design as } \\
\text { compromise between dike } \\
\text { stability and material } \\
\text { consumption/footprint }\end{array}$ & $\begin{array}{l}\text { Milder seaward slopes for } \\
\text { positive effects on nature, } \\
\text { recreation and coastal processes }\end{array}$ & $\begin{array}{l}\text { Increased dike footprint, additional } \\
\text { habitat loss/alteration }\end{array}$ \\
\hline Dike roads & Asphalt roads & $\begin{array}{l}\text { Alternative vegetated fortified } \\
\text { paths (e.g., vegetated geocellular } \\
\text { containment systems) }\end{array}$ & $\begin{array}{l}\text { Little experience, mainly pilot projects. } \\
\text { Assurance of stability and functionality }\end{array}$ \\
\hline Revetments & $\begin{array}{l}\text { Grey revetments (rip-rap, } \\
\text { placed blocks, etc.) }\end{array}$ & $\begin{array}{l}\text { Vegetated or colonized } \\
\text { revetments }\end{array}$ & $\begin{array}{l}\text { Little experience, mainly pilot projects. } \\
\text { Assurance of stability and functionality }\end{array}$ \\
\hline $\begin{array}{l}\text { Vegetated dike } \\
\text { cover }\end{array}$ & $\begin{array}{l}\text { Dense grass covers, no } \\
\text { woody vegetation }\end{array}$ & $\begin{array}{l}\text { Adaptation of seeding mixtures } \\
\text { towards more ecologically } \\
\text { valuable vegetation }\end{array}$ & $\begin{array}{l}\text { Assurance of consistent erosion } \\
\text { resistance }\end{array}$ \\
\hline
\end{tabular}

The integration of ecosystem-based engineering in the foreshore, e.g., with natural ecosystems or nature-based breakwaters in the form of reefs, allows for ecological enhancement and decreased hydraulic loads at the dike structure [8,47]. The target species has to be chosen according to boundary conditions, such as climate, salinity, exposure to hydrodynamic loads, submergence time and substrate [8]. Colonization with corals e.g., depends on the availability of hard substrate; mangroves require muddy systems. Similarly, mangroves can only be found in tropical or subtropical regions, while salt marshes occur in temperate regions. Little experience with the establishment and management of natural solutions still poses a challenge. However, lately, innovative nature-based methods are investigated for foreshore restoration, such as wave breakers made of oyster-bags [117] and reef balls [118]. Furthermore, artificial sea grass beds are investigated regarding their potential to support the long-term rehabilitation of natural sea grass [119]. Uncertainties concerning the coastal protection function of ecosystems [45,46], e.g., due to their spatial and temporal variability, have to be considered in the design process. Depending on the ecosystem, aboveground biomass may vary over the year resulting in temporal differences in energy dissipation and sediment accretion. Exemplarily, a reduction of shoot densities from around 4600 shoots $/ \mathrm{m}^{2}$ in summer to 600 shoots $/ \mathrm{m}^{2}$ in winter was found for a seagrass meadow and largest wave height reductions were recorded in July when the shoot density was high [120]. Additionally, vegetation may break or fold under extreme wave loads resulting in reduced coastal protection benefits [121]. In case that the aboveground biomass disappears completely, only the trapped sediments can yield wave attenuation [45].

Adaptations of the general dike geometry, such as milder seaward slopes, can have positive effects on nature, recreation and coastal processes [6,48]. Considering milder slopes for ecological enhancement of sea dikes, the various aspects-additional habitat loss/alteration, alteration of coastal processes-have to be evaluated as well as further conflicts, e.g., due to space restrictions, have to be considered.

A more natural approach to asphalt-paved dike roads may be alternative methods, such as vegetated geocellular containment systems [49]. Considering alternative design methods for the construction of dike roads, more comprehensive investigations are required, especially concerning the assurance of stability and functionality under extreme conditions. 
Dike revetments can be enhanced ecologically by introducing vegetation by means of provision of substrate within cavities [51] or reduction of surface sealing [55]. Experience with these approaches is, however, mainly limited to pilot projects. Colonization with organisms can be supported by means of surface adaptions, e.g., more inhomogeneous surface structures or water retaining features [58]. Yet, studies on the colonization of revetments mainly focus on the subtidal and intertidal zone while for dikes generally only the dike toe is affected by tidal water fluctuations. Colonization of dike revetments may therefore be limited. Generally, the stability and functionality of the revetment have to be ensured for every change of the original revetment system, e.g., changes in permeability or root growth within revetment cavities and possibly filter layers.

Based on experience and supported by comprehensive laboratory and field studies [74,76,82], commonly grasses are used for dike vegetation (Figure 4, left) since a dense grass cover is known to provide sufficient surface protection against moderate hydraulic, climatic and mechanical loads [1]. Enhancements of the ecological value of the dike vegetation are possible by adapting the seeding mixtures towards species compositions that offer more food sources for flower-visiting insects or more carbon sequestration (Figure 4, right). When adapting the vegetation on dikes, the erosion resistance still has to be assured. Currently, different vegetation mixtures are investigated concerning their ecological value, erosion resistance and vegetation development under coastal conditions within the EcoDike project [122]. Concerning maintenance measures such as mowing or grazing, the demands of coastal protection and ecology have to be reconciled, though dike safety is of primary importance. For compensation of probably decreased erosion resistance, the application of grass reinforcements may be possible. Woody vegetation on dikes is generally not welcome except special adaptation measures are taken [91,92].
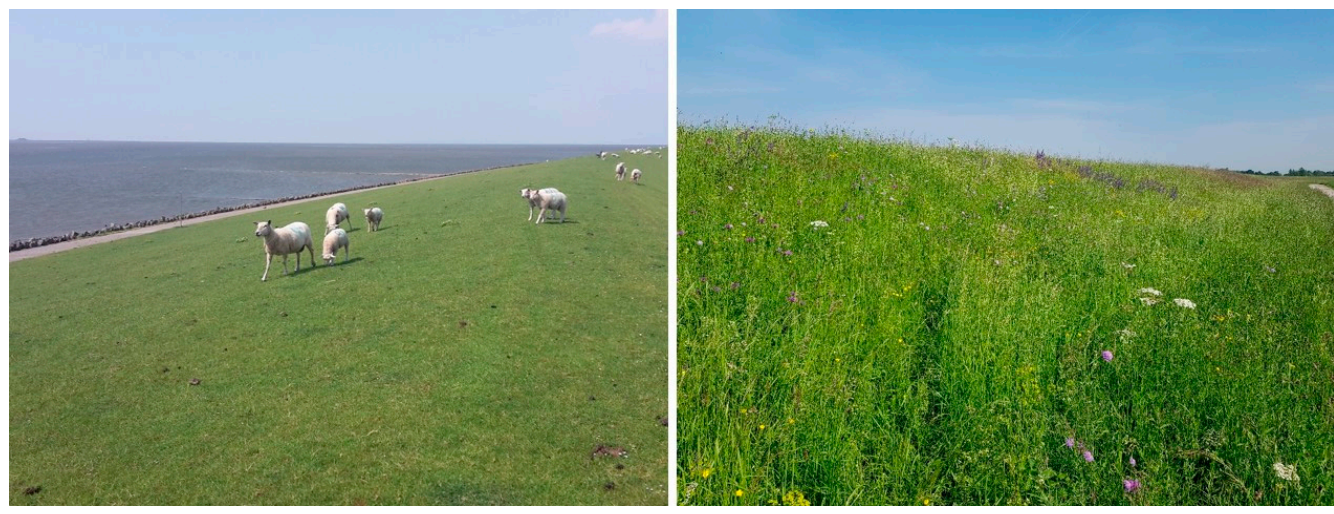

Figure 4. Left: Typical grass-covered sea dike on Pellworm, Germany (Photo: Scheres, 2018); Right: Species-rich vegetation on a river dike along the Lower Rhine in Meerbusch, Germany (Photo: Scheres, 2019).

\subsection{Bringing Together Ecology, Engineering and Society}

Designing and implementing ecological enhancements and nature-based solutions in coastal protection not only requires the interdisciplinary collaboration of scientists (especially ecologists) and engineers, but also brings societal challenges, such as the necessity to consider different interests, knowledge and language of the various stakeholders in science, practice, policy and public $[123,124]$. The design and implementation of ecologically valuable sea dikes requires interdisciplinary cooperation acknowledging the demands and objectives of the different parties and focusing on the common interests of ecology, engineering and society. Developing an integrated concept for ecologically enhanced sea dikes, the dike system has to be understood and promoted as part of a greater ecosystem.

While a dike functions as a coastal protection structure (relevant for engineering and society, Figure 5), it can simultaneously provide habitat for coastal flora and fauna and thereby give ecological benefits (relevant for ecology and society, Figure 5). For enhancing the ecological value of coastal structures, ecological engineering as a merger of ecology and engineering (Figure 5) has to be applied. 
To finally achieve ecologically valuable coastal protection, the interests of all stakeholders have to be brought together. Conflicts may arise if objectives, approaches or mindsets differ [125].

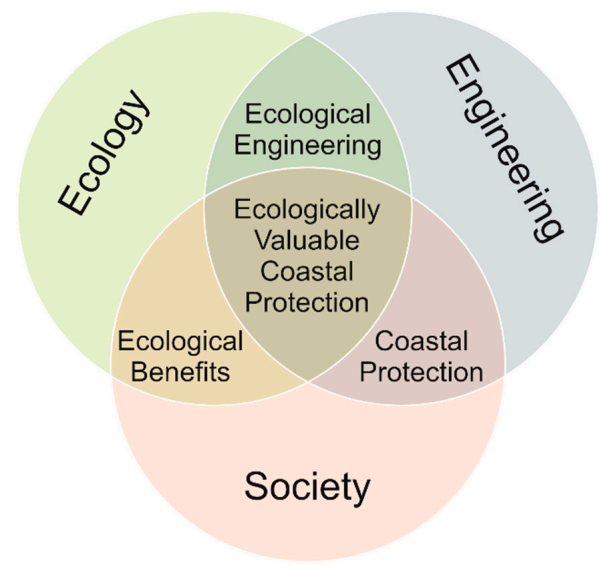

Figure 5. Bringing together the interests of ecology, engineering and society to achieve ecologically valuable coastal protection.

Overcoming knowledge and language differences [126,127], adjusted operational instruments, e.g., by involving knowledge brokers [123], direct participation of stakeholders, e.g., within participatory or collaborative modelling approaches [128], and cost-benefit analyses under consideration of ecosystem services $[129,130]$ can form a basis for decision-making and help to overcome possible conflicts.

\section{Conclusions}

Sea dikes pose an important coastal protection element along coasts with low-lying hinterlands. For the design and maintenance of dikes, dike safety is the main factor to assure constant and sufficient protection against the forces of the sea. When adapting the original system, the dike safety has to be maintained.

Ecological enhancement of sea dike systems can be obtained by means of natural or nature-based solutions in the foreland or at the dike structure itself. Natural (marshes, reefs, etc.) or engineered approaches (artificial reefs, etc.) can support ecosystems in the foreland and can simultaneously decrease the loads on the dike structure resulting in longer design lives and reduced maintenance efforts. Ecological enhancements of the dike structure itself, e.g., vegetated revetments or ecologically valuable sea dike vegetation, allow for further increase of the ecological value of the sea dike system. Introducing new design methods, the stability and functionality of the coastal protection structure have to be assured, e.g., maintenance of the erosion resistance of vegetation covers when adapting the vegetation species applied.

While a wide range of studies focuses on natural and nature-based solutions in the foreland, so far only few experiences with ecological enhancements of the dike structure itself were gained resulting in uncertainties and knowledge gaps concerning the implementation and efficiency (technical and ecological). To account for increasing hydraulic loads and environmental awareness, engineers and ecologists from science and practice are obliged to take joint steps towards greener, adapted coastal protection.

Author Contributions: Conceptualization, B.S. and H.S.; formal analysis/review, B.S.; writing—original draft preparation, B.S.; writing—review and editing, H.S.; visualization, B.S.; supervision, H.S.; project administration, H.S.; funding acquisition, H.S. and others.

Funding: This research was funded by the German Federal Ministry of Education and Research (BMBF) within the project EcoDike, grant number 03F0757 A.

Conflicts of Interest: The authors declare no conflict of interest. The funders had no role in the design of the study; in the collection, analyses, or interpretation of data; in the writing of the manuscript, or in the decision to publish the results. 


\section{Appendix A}

Table A1. Summary of studies on the erosion resistance of vegetated dike covers against wave overtopping and overflow. Abbreviations: $\mathrm{q}=\mathrm{mean}$ overtopping/overflow

discharge $[1 /(\mathrm{sm})], \mathrm{V}_{\text {total }}=$ cumulative overtopping volume $\left[\mathrm{m}^{3} / \mathrm{m}\right]$, WOS = Wave Overtopping Simulator. * Festuca Rubra, Lolium perenne and Poa pratensis;

** Trifolium repen and Medicago sativa.

\begin{tabular}{|c|c|c|c|c|c|}
\hline Ref & Test Object & Material of Cover & Vegetation & Loads & Results \\
\hline \multicolumn{6}{|c|}{ Model tests in wave flumes } \\
\hline [74] & $\begin{array}{l}\text { sea dike model, } \\
\text { 1:3 landward slope }\end{array}$ & $\begin{array}{l}3 \text { different clays } \\
\text { tested }\end{array}$ & no vegetation & $\begin{array}{l}\text { q up to } 10 \mathrm{l} /(\mathrm{sm}) \\
\mathrm{H}_{\mathrm{S}} \text { unknown }\end{array}$ & - erosion initiation due to $\mathrm{q}<1.0 \mathrm{l} /(\mathrm{sm})$ [good clay] \\
\hline [75] & $\begin{array}{l}\text { sea dike model, } \\
\text { 1:3 landward slope }\end{array}$ & clay & $\begin{array}{l}\text { grass sods from Ribe, } \\
\text { Denmark }\end{array}$ & $\begin{array}{l}\text { qup to } 30 \mathrm{l} /(\mathrm{sm}) \\
\mathrm{H}_{\mathrm{S}}=0.75-1.0 \mathrm{~m}\end{array}$ & - $\quad$ no damage (visual assessment) \\
\hline \multicolumn{6}{|c|}{ In-situ tests on real dikes } \\
\hline [76] & $\begin{array}{l}\text { sea dikes in the Netherlands, } \\
\text { several test locations }\end{array}$ & clay & $\begin{array}{l}\text { various grass conditions } \\
\text { and maintenance } \\
\text { strategies }\end{array}$ & $\begin{array}{l}\text { Dutch WOS } \\
\text { qup to } 75 \mathrm{l} /(\mathrm{sm}) \\
\mathrm{H}_{\mathrm{S}}=2 \mathrm{~m}\end{array}$ & $\begin{array}{ll}\text { - } & \text { no dike failure due to } \mathrm{q}=30 \mathrm{l} /(\mathrm{sm}) \\
\text { - } & \text { one dike failure due to } \mathrm{q}=50 \mathrm{l} /(\mathrm{sm}) \text { [bad grass coverage }]\end{array}$ \\
\hline [77] & $\begin{array}{l}\text { sea dikes in the Netherlands } \\
\text { (here only Vecht dike) }\end{array}$ & $90 \%$ sand & $\begin{array}{l}\text { grass cover in a good } \\
\text { condition }\end{array}$ & $\begin{array}{c}\text { Dutch WOS } \\
\text { qup to } 50 \mathrm{l} /(\mathrm{sm}) \\
\mathrm{H}_{\mathrm{S}}=1 \mathrm{~m} \text { and } 3 \mathrm{~m}\end{array}$ & $\begin{array}{ll}\text { - } & \text { erosion initiation due to } \mathrm{q}=30 \mathrm{l} /(\mathrm{sm})\left[\mathrm{H}_{\mathrm{S}}=1 \mathrm{~m}\right] \\
\text { - } & \text { erosion initiation due to } \mathrm{q}=5 \mathrm{l} /(\mathrm{sm})\left[\mathrm{H}_{\mathrm{S}}=3 \mathrm{~m}\right] \\
\text { - } & \text { head-cut erosion due to } \mathrm{q}=30 \mathrm{l} /(\mathrm{sm})\left[\mathrm{H}_{\mathrm{S}}=3 \mathrm{~m}\right]\end{array}$ \\
\hline \multirow[t]{4}{*}{ [78] } & $\begin{array}{l}\text { Vietnamese sea dikes, } \\
1: 3 \& 1: 15 \text { landward slope }\end{array}$ & moderate clay & Bermuda grass & $\begin{array}{l}\text { Dutch WOS } \\
\text { q up to } 701 /(\mathrm{sm}) \\
\mathrm{H}_{\mathrm{S}}=1.5 \mathrm{~m}\end{array}$ & $\begin{array}{ll}\text { - } & \text { erosion initiation due to } \mathrm{q}=40 \mathrm{l} /(\mathrm{sm}) \text { [good Bermuda] } \\
\text { - } & \text { erosion initiation due to } \mathrm{q}=10 \mathrm{l} /(\mathrm{sm}) \text { [poor Bermuda with Casuarina tree] } \\
\text { erosion initiation due to } \mathrm{q}=20 \mathrm{l} /(\mathrm{sm}) \text { [very poor Bermuda] }\end{array}$ \\
\hline & & good clay & $\begin{array}{l}\text { Bermuda and Vetiver } \\
\text { grass }\end{array}$ & $\begin{array}{l}\text { Dutch WOS } \\
\text { q up to } 1201 /(\mathrm{sm}) \\
\mathrm{H}_{\mathrm{S}}=1.5 \mathrm{~m}\end{array}$ & $\begin{array}{l}\text { - } \quad \text { erosion initiation due to } \mathrm{q}=80 \mathrm{l} /(\mathrm{sm}) \text { [good and poor grass condition] } \\
\text { - }\end{array}$ \\
\hline & & good clay & $\begin{array}{l}\text { young Bermuda grass } \\
\text { (1-year, good condition) }\end{array}$ & $\begin{array}{l}\text { Dutch WOS } \\
\text { q up to } 1101 /(\mathrm{sm}) \\
\mathrm{H}_{\mathrm{S}}=1.5 \mathrm{~m}\end{array}$ & - $\quad$ erosion initiation due to $\mathrm{q}=100 \mathrm{l} /(\mathrm{sm})$ \\
\hline & & good clay & $\begin{array}{l}\text { young Carpet grass } \\
\text { (1-year, good condition) }\end{array}$ & $\begin{array}{c}\text { Dutch WOS } \\
\text { q up to } 100 \mathrm{l} /(\mathrm{sm}) \\
\mathrm{H}_{\mathrm{S}}=1.5 \mathrm{~m} \text { and } 2 \mathrm{~m}\end{array}$ & - erosion initiation due to (1) $\mathrm{q}=60 \mathrm{l} /(\mathrm{sm})$ and $(2) \mathrm{q}=100 \mathrm{l} /(\mathrm{sm})\left[\mathrm{H}_{\mathrm{S}}=2 \mathrm{~m}\right]$ \\
\hline
\end{tabular}


Table A1. Cont.

\begin{tabular}{|c|c|c|c|c|c|}
\hline Ref & Test Object & Material of Cover & Vegetation & Loads & Results \\
\hline \multirow[t]{2}{*}{ [79] } & \multirow[t]{2}{*}{$\begin{array}{l}\text { tidal river dike in Belgium, } \\
\text { 1:1.7 landward slope }\end{array}$} & clay & grass in poor condition & $\begin{array}{l}\text { Dutch WOS } \\
\text { q up to } 25 \mathrm{l} /(\mathrm{sm}) \\
\mathrm{H}_{\mathrm{S}} \text { up to } 1.2 \mathrm{~m}\end{array}$ & $\begin{array}{l}\text { - } \quad \text { erosion initiation due to } \mathrm{q}=10 \mathrm{l} /(\mathrm{sm}) \text { at rabbit hole } \\
\text { dike failure due to } \mathrm{q}=25 \mathrm{l} /(\mathrm{sm})\end{array}$ \\
\hline & & clay & grass in poor condition & $\begin{array}{l}\text { Overflow simulator } \\
\text { q up to } 1701 /(\mathrm{sm})\end{array}$ & - no/minor erosion due to $\mathrm{q}=170 \mathrm{l} /(\mathrm{sm})$ \\
\hline \multicolumn{6}{|c|}{ Model tests on artificial research dikes/dike covers } \\
\hline \multirow[t]{3}{*}[81,82]{} & \multirow[t]{3}{*}{ planter trays on 1:3 slope } & clay & no vegetation & $\begin{array}{l}\text { US WOS } \\
\text { q up to } 18.61 /(\mathrm{sm}) \\
\mathrm{H}_{\mathrm{S}}=2.44 \mathrm{~m}\end{array}$ & $\begin{array}{l}\text { - } \quad \text { severe erosion after } 1 \mathrm{~h} \text { of } \mathrm{q}=9.3 \mathrm{l} /(\mathrm{sm}) \\
\quad \text { failure due to } \mathrm{V}_{\text {total }}=56 \mathrm{~m}^{3} / \mathrm{m}\end{array}$ \\
\hline & & clay & Bermuda grass & $\begin{array}{l}\text { US WOS } \\
\text { qup to } 370 \mathrm{l} /(\mathrm{sm}) \\
\mathrm{H}_{\mathrm{S}}=2.44 \mathrm{~m}\end{array}$ & $\begin{array}{l}\text { - } \quad \text { no damage due to } \mathrm{V}_{\text {total }}=16,522 \mathrm{~m}^{3} / \mathrm{m} \text { [well-maintained, dense Bermuda grass] } \\
\text { - } \\
\text { - } \\
\text { - } \\
\text { finor erosilure due to } \mathrm{V}_{\text {total }}=2,175 \mathrm{~m}^{3} / \mathrm{m} \text { [dormant Bermuda grass] }\end{array}$ \\
\hline & & clay & Bahia grass & $\begin{array}{c}\text { US WOS } \\
\text { q up to } 2791 /(\mathrm{sm}) \\
\mathrm{H}_{\mathrm{S}}=2.44 \mathrm{~m}\end{array}$ & - $\quad$ no damage due to $\mathrm{V}_{\text {total }}=13,244 \mathrm{~m}^{3} / \mathrm{m}$ \\
\hline [82] & planter trays on 1:3 slope & $\begin{array}{l}4 \text { different sandy } \\
\text { soils }\end{array}$ & $\begin{array}{l}\text { Bahia grass, } 50 \% \text { and } 30 \% \\
\text { grass coverage }\end{array}$ & $\begin{array}{l}\text { US WOS } \\
\mathrm{H}_{\mathrm{S}} \text { up to } 2.44 \mathrm{~m}\end{array}$ & $\begin{array}{l}\text { - failure due to } \mathrm{V}_{\text {total }}=301 \text { to } 1,354 \mathrm{~m}^{3} / \mathrm{m} \\
\text { - correlation of hydraulic resistance and root parameters (average root length } \\
\text { and volume) }\end{array}$ \\
\hline [80] & $\begin{array}{l}\text { research dike, } 1: 2 \& 1: 3 \\
\text { landward slope }\end{array}$ & $\begin{array}{l}\text { fine-grained } \\
\text { dredged material }\end{array}$ & $\begin{array}{l}\text { standard dike seeding } \\
\text { mixture* with added } \\
\text { legumes } * * \text { good } \\
\text { vegetation coverage }\end{array}$ & $\begin{array}{l}\text { overflow tests } \\
\text { max. } \mathrm{q}>550 \mathrm{l} /(\mathrm{sm}) \\
\text { max. } \mathrm{v}>4.6 \mathrm{~m} / \mathrm{s}\end{array}$ & $\begin{array}{l}\text { - measured average cumulative soil loss did not exceed the critical amount of soil } \\
\text { loss }(1.27 \mathrm{~cm})\end{array}$ \\
\hline
\end{tabular}




\section{References}

1. Construction Industry Research and Information Association (CIRIA). The International Levee Handbook; CIRIA: London, UK, 2013; ISBN 978-0-86017-734-0.

2. Schüttrumpf, H. Sea Dikes in Germany. In Die Küste; Kuratorium für Forschung im Küsteningenieurwesen, Ed.; Boyens Medien GmbH \& Co. KG: Heide i. Holstein, Germany, 2008; pp. 189-199.

3. Thorenz, F. Coastal Flood Defence and Coastal Protection along the North Sea Coast of Niedersachsen. In Die Küste; Kuratorium für Forschung im Küsteningenieurwesen, Ed.; Boyens Medien GmbH \& Co. KG: Heide i. Holstein, Germany, 2008; pp. 158-169.

4. Rockström, J.; Steffen, W.; Noone, K.; Persson, A.; Chapin, F.S.; Lambin, E.F.; Lenton, T.M.; Scheffer, M.; Folke, C.; Schellnhuber, H.J.; et al. A safe operating space for humanity. Nature 2009, 461, 472-475. [CrossRef] [PubMed]

5. Cheong, S.-M.; Silliman, B.; Wong, P.P.; van Wesenbeeck, B.; Kim, C.-K.; Guannel, G. Coastal adaptation with ecological engineering. Nat. Clim. Chang. 2013, 3, 787-791. [CrossRef]

6. Van Loon-Steensma, J.M.; Schelfhout, H.A.; Vellinga, P. Green adaptation by innovative dike concepts along the Dutch Wadden Sea coast. Environ. Sci. Policy 2014, 44, 108-125. [CrossRef]

7. Sutton-Grier, A.E.; Wowk, K.; Bamford, H. Future of our coasts: The potential for natural and hybrid infrastructure to enhance the resilience of our coastal communities, economies and ecosystems. Environ. Sci. Policy 2015, 51, 137-148. [CrossRef]

8. Van Wesenbeeck, B.K.; van der Meulen, M.D.; Pesch, C.; de Vriend, H.; de Vries, M.B. Nature-Based Approaches in Coastal Flood Risk Management: Physical Restrictions and Engineering Challenges. In Ecosystem-Based Disaster Risk Reduction and Adaptation in Practice; Renaud, F.G., Sudmeier-Rieux, K., Estrella, M., Nehren, U., Eds.; Springer International Publishing: Cham, Switzerland, 2016; pp. 181-198. ISBN 978-3-319-43631-9.

9. Hood, W.G. Indirect environmental effects of dikes on estuarine tidal channels: Thinking outside of the dike for habitat restoration and monitoring. Estuaries 2004, 27, 273-282. [CrossRef]

10. Temmerman, S.; Meire, P.; Bouma, T.J.; Herman, P.M.J.; Ysebaert, T.; de Vriend, H.J. Ecosystem-based coastal defence in the face of global change. Nature 2013, 504, 79-83. [CrossRef] [PubMed]

11. Empfehlungen für die Ausführung von Küstenschutzwerken (EAK). Empfehlungen für Küstenschutzwerke: Korrigierte Ausgabe 2002. In Die Küste; Kuratorium für Forschung im Küsteningenieurwesen, Ed.; Bundesanstalt für Wasserbau (BAW): Karlsruhe, Germany, 2002.

12. Sheaves, M. Consequences of ecological connectivity: The coastal ecosystem mosaic. Mar. Ecol. Prog. Ser. 2009, 391, 107-115. [CrossRef]

13. Olds, A.D.; Connolly, R.M.; Pitt, K.A.; Pittman, S.J.; Maxwell, P.S.; Huijbers, C.M.; Moore, B.R.; Albert, S.; Rissik, D.; Babcock, R.C.; et al. Quantifying the conservation value of seascape connectivity: A global synthesis. Glob. Ecol. Biogeogr. 2016, 25, 3-15. [CrossRef]

14. Scheres, B.; Schüttrumpf, H. Conception of Ecologically Valuable Sea Dike Systems. In The Thirteenth International MEDCOAST Congress on Coastal and Marine Sciences, Engineering, Management and Conservation; MEDCOAST 17; Mediterranean Coastal Foundation: Mellieha, Malta, 2017; pp. 893-904. ISBN 978-605-85652-6-5.

15. Jones, C.G.; Lawton, J.H.; Shachak, M. Organisms as ecosystem engineers. Oikos 1994, 69, 373-386. [CrossRef]

16. Jones, C.G.; Lawton, J.H.; Shachak, M. Positive and negative effects of organisms as ecosystem engineers. Ecology 1997, 78, 1946-1957. [CrossRef]

17. Chapin, F.S., III; Matson, P.A.; Vitousek, P.M. Principles of Terrestrial Ecosystem Ecology, 2nd ed.; Imprint; Springer: New York, NY, USA, 2011; ISBN 978-1-4419-9504-9.

18. Millennium Ecosystem Assessment. Ecosystems and Human Well-Being. Synthesis: A Report of the Millennium Ecosystems Assessment; Island Press: Washington, DC, USA, 2005; ISBN 1-59726-040-1.

19. National Research Council. Valuing Ecosystem Services; National Academies Press: Washington, DC, USA, 2004; ISBN 978-0-309-09318-7.

20. Arkema, K.K.; Verutes, G.M.; Wood, S.A.; Clarke-Samuels, C.; Rosado, S.; Canto, M.; Rosenthal, A.; Ruckelshaus, M.; Guannel, G.; Toft, J.; et al. Embedding ecosystem services in coastal planning leads to better outcomes for people and nature. Proc. Natl. Acad. Sci. USA 2015, 112, 7390-7395. [CrossRef] [PubMed] 
21. Gutiérrez, J.L.; Jones, C.G.; Byers, J.E.; Arkema, K.K.; Berkenbusch, K.; Commito, J.A.; Duarte, C.M.; Hacker, S.D.; Lambrinos, J.G.; Hendriks, I.E.; et al. Physical ecosystem engineers and the functioning of estuaries and coasts. In Treatise on Estuarine and Coastal Science; Elsevier: Amsterdam, The Netherlands, 2011; pp. 53-81. ISBN 9780080878850.

22. Barbier, E.B.; Hacker, S.D.; Kennedy, C.; Koch, E.W.; Stier, A.C.; Silliman, B.R. The value of estuarine and coastal ecosystem services. Ecol. Monogr. 2011, 81, 169-193. [CrossRef]

23. Spalding, M.D.; Ruffo, S.; Lacambra, C.; Meliane, I.; Hale, L.Z.; Shepard, C.C.; Beck, M.W. The role of ecosystems in coastal protection: Adapting to climate change and coastal hazards. Ocean Coast. Manag. 2014, 90, 50-57. [CrossRef]

24. Narayan, S.; Beck, M.W.; Reguero, B.G.; Losada, I.J.; van Wesenbeeck, B.; Pontee, N.; Sanchirico, J.N.; Ingram, J.C.; Lange, G.-M.; Burks-Copes, K.A. The effectiveness, costs and coastal protection benefits of natural and nature-based defences. PLoS ONE 2016, 11, e0154735. [CrossRef] [PubMed]

25. Van Wesenbeeck, B.K.; de Boer, W.; Narayan, S.; van der Star, W.R.L.; de Vries, M.B. Coastal and riverine ecosystems as adaptive flood defenses under a changing climate. Mitig. Adapt. Strateg. Glob. Chang. 2016, 22, 1087-1094. [CrossRef]

26. De Vriend, H.J. Building with Nature: Mainstreaming the Concept. In Proceedings of the 11th International Conference on Hydroscience \& Engineering (ICHE 2014), Hamburg, Germany, 28 September-2 October 2014; Lehfeldt, R., Kopmann, R., Eds.; pp. 29-36, ISBN 978-3-939230-32-8.

27. De Vriend, H.; van Koningsveld, M.; Aarninkhof, S. 'Building with nature': The new Dutch approach to coastal and river works. Proc. Inst. Civ. Eng. Civ. Eng. 2014, 167, 18-24. [CrossRef]

28. Bridges, T.; Bourne, E.M.; King, J.; Kuzmitski, H.; Moynihan, E.; Suedel, B. Engineering with Nature: An Atlas; U.S. Army Engineer Research and Development Center: Vicksburg, Mississippi, USA, 2018; ISBN 9781732590403.

29. SAGE. Natural and Structural Measures for Shoreline Stabilization. Available online: http://www.sagecoast. org/docs/SAGE_LivingShorelineBrochure_Print.pdf (accessed on 2 July 2019).

30. Borsje, B.W.; van Wesenbeeck, B.K.; Dekker, F.; Paalvast, P.; Bouma, T.J.; van Katwijk, M.M.; de Vries, M.B. How ecological engineering can serve in coastal protection. Ecol. Eng. 2011, 37, 113-122. [CrossRef]

31. Pontee, N.; Narayan, S.; Beck, M.W.; Hosking, A.H. Nature-based solutions: Lessons from around the world. Proc. Inst. Civ. Eng. Marit. Eng. 2016, 169, 29-36. [CrossRef]

32. Schoonees, T.; Gijón Mancheño, A.; Scheres, B.; Bouma, T.J.; Silva, R.; Schlurmann, T.; Schüttrumpf, H. Hard structures for coastal protection, towards greener designs. Estuaries Coasts 2019, 21, 755. [CrossRef]

33. Kirwan, M.L.; Megonigal, J.P. Tidal wetland stability in the face of human impacts and sea-level rise. Nature 2013, 504, 53-60. [CrossRef]

34. Bradley, K.; Houser, C. Relative velocity of seagrass blades: Implications for wave attenuation in low-energy environments. J. Geophys. Res. 2009, 114, 67. [CrossRef]

35. McIvor, A.; Möller, I.; Spencer, T.; Spalding, M. Reduction of Wind and Swell Waves by Mangroves. Natural Coastal Protection Series: Report 1; Cambridge Coastal Research Unit Working Paper 40; The Nature Conservancy and Wetlands International: Cambridge, UK, 2012; Available online: https://www.conservationgateway.org/ConservationPractices/Marine/crr/library/Documents/windand-swell-wave-reduction-by-mangroves.pdf (accessed on 2 July 2019).

36. Möller, I.; Spencer, T.; French, J.R.; Leggett, D.J.; Dixon, M. Wave transformation over salt marshes: A field and numerical modelling study from North Norfolk, England. Estuar. Coast. Shelf Sci. 1999, 49, 411-426. [CrossRef]

37. Vuik, V.; Borsje, B.W.; Willemsen, P.W.J.M.; Jonkman, S.N. Salt marshes for flood risk reduction: Quantifying long-term effectiveness and life-cycle costs. Ocean Coast. Manag. 2019, 171, 96-110. [CrossRef]

38. Gacia, E.; Granata, T.C.; Duarte, C.M. An approach to measurement of particle flux and sediment retention within seagrass (Posidonia oceanica) meadows. Aquat. Bot. 1999, 65, 255-268. [CrossRef]

39. Kirwan, M.L.; Guntenspergen, G.R.; D'Alpaos, A.; Morris, J.T.; Mudd, S.M.; Temmerman, S. Limits on the adaptability of coastal marshes to rising sea level. Geophys. Res. Lett. 2010, 37. [CrossRef]

40. Krauss, K.W.; McKee, K.L.; Lovelock, C.E.; Cahoon, D.R.; Saintilan, N.; Reef, R.; Chen, L. How mangrove forests adjust to rising sea level. New Phytol. 2014, 202, 19-34. [CrossRef]

41. Ferrario, F.; Beck, M.W.; Storlazzi, C.D.; Micheli, F.; Shepard, C.C.; Airoldi, L. The effectiveness of coral reefs for coastal hazard risk reduction and adaptation. Nat. Commun. 2014, 5, 3794. [CrossRef] 
42. Piazza, B.P.; Banks, P.D.; La Peyre, M.K. The potential for created oyster shell reefs as a sustainable shoreline protection strategy in Louisiana. Restor. Ecol. 2005, 13, 499-506. [CrossRef]

43. Kochmann, J.; Buschbaum, C.; Volkenborn, N.; Reise, K. Shift from native mussels to alien oysters: Differential effects of ecosystem engineers. J. Exp. Mar. Biol. Ecol. 2008, 364, 1-10. [CrossRef]

44. Wild, C.; Huettel, M.; Klueter, A.; Kremb, S.G.; Rasheed, M.Y.M.; Jorgensen, B.B. Coral mucus functions as an energy carrier and particle trap in the reef ecosystem. Nature 2004, 428, 66-70. [CrossRef]

45. Bouma, T.J.; van Belzen, J.; Balke, T.; Zhu, Z.; Airoldi, L.; Blight, A.J.; Davies, A.J.; Galvan, C.; Hawkins, S.J.; Hoggart, S.P.G.; et al. Identifying knowledge gaps hampering application of intertidal habitats in coastal protection: Opportunities \& steps to take. Coast. Eng. 2014, 87, 147-157. [CrossRef]

46. Spalding, M.D.; McIvor, A.L.; Beck, M.W.; Koch, E.W.; Möller, I.; Reed, D.J.; Rubinoff, P.; Spencer, T.; Tolhurst, T.J.; Wamsley, T.V.; et al. Coastal ecosystems: A critical element of risk reduction. Conserv. Lett. 2014, 7, 293-301. [CrossRef]

47. Sutton-Grier, A.E.; Gittman, R.K.; Arkema, K.K.; Bennett, R.O.; Benoit, J.; Blitch, S.; Burks-Copes, K.A.; Colden, A.; Dausman, A.; DeAngelis, B.M.; et al. Investing in natural and nature-based infrastructure: Building better along our coasts. Sustainability 2018, 10, 523. [CrossRef]

48. Dugan, J.E.; Airoldi, L.; Chapman, M.G.; Walker, S.J.; Schlacher, T. Estuarine and Coastal Structures: Environmental Effects, A Focus on Shore and Nearshore Structures. In Treatise on Estuarine and Coastal Science; Academic Press: Waltham, MA, USA, 2011; pp. 17-41. ISBN 9780080878850.

49. Meyer, M.; Emersleben, A. Einsatz von Geozellen im Deich- und Wasserbau. In Sicherung von Dämmen, Deichen und Stauanlagen: Handbuch für Theorie und Praxis Vol. III; Herrmann, R.A., Jürgen, J., Eds.; Universitätsverlag Siegen: Siegen, Germany, 2009; pp. 431-443. ISBN 978-3-936533-33-0.

50. Construction Industry Research and Information Association (CIRIA). The Rock Manual. The Use of Rock in Hydraulic Engineering, 2nd ed.; CIRIA: London, UK, 2007; ISBN 978-0-86017-683-1.

51. Gewatech. Begrünung von Deckwerken. Available online: http://www.gewatech.de/deu/begruenung_von_ deckwerken.html (accessed on 2 July 2019).

52. Trentmann, J. Dichtung aus Wasserbausteinen mit Vollverguss aus hydraulisch gebundenem Vergussstoff. KW Korrespondenz Wasserwirtschaft 2011, 4, 452-458.

53. Wilke, M.; Krueger, B.; Schuell, M.; Tschernutter, P. Erosion Resistant Construction of Overflow Sections by means of Geosynthetic Concrete Mattresses. In Proceedings of the 6th International Conference on Scour and Erosion (ICSE-6), Paris, France, 27-31 August 2012; Fry, J.-J., Chevalier, C., Eds.; Société Hydrotechnique de France: Paris, France, 2012; pp. 1231-1238.

54. Shoretec. Shoreblock ${ }^{\circledR}$ BD Series: Concrete Revetment Block. Available online: http://www.shoretec.com/ downloads/bd-brochure.pdf (accessed on 2 July 2019).

55. Mohamed, T.A.; Alias, N.A.; Ghazali, A.H.; Jaafar, M.S. Evaluation of environmental and hydraulic performance of bio-composite revetment blocks. Am. J. Environ. Sci. 2006, 2, 129-134. [CrossRef]

56. Coombes, M.A.; La Marca, E.C.; Naylor, L.A.; Thompson, R.C. Getting into the groove: Opportunities to enhance the ecological value of hard coastal infrastructure using fine-scale surface textures. Ecol. Eng. 2015, 77, 314-323. [CrossRef]

57. Hall, A.E.; Herbert, R.J.H.; Britton, J.R.; Hull, S.L. Ecological enhancement techniques to improve habitat heterogeneity on coastal defence structures. Estuar. Coast. Shelf Sci. 2018, 210, 68-78. [CrossRef]

58. Strain, E.M.A.; Olabarria, C.; Mayer-Pinto, M.; Cumbo, V.; Morris, R.L.; Bugnot, A.B.; Dafforn, K.A.; Heery, E.; Firth, L.B.; Brooks, P.R.; et al. Eco-engineering urban infrastructure for marine and coastal biodiversity: Which interventions have the greatest ecological benefit? J. Appl. Ecol. 2017, 55, 426-441. [CrossRef]

59. Dafforn, K.A.; Glasby, T.M.; Johnston, E.L. Comparing the invasibility of experimental "reefs" with field observations of natural reefs and artificial structures. PLoS ONE 2012, 7, e38124. [CrossRef]

60. Sella, I.; Perkol-Finkel, S. Blue is the new green-Ecological enhancement of concrete based coastal and marine infrastructure. Ecol. Eng. 2015, 84, 260-272. [CrossRef]

61. Technical Advisory Committee for Flood Defence (TAW). Grass Cover as a Dike Revetment; TAW: Delft, The Netherlands, 1999.

62. U. S. Army Corps of Engineers (USACE). Guidelines for Landscape Planting and Vegetation Management at Levees, Floodwalls, Embankment Dams, and Appurtenant Structures; Technical Letter No. ETL 1120-2-583; USACE: Washington, DC, USA, 2014. 
63. Gray, D.H. Influence of Vegetation on the Stability of Slopes. In Vegetation and Slopes: Stabilisation, Protection, and Ecology, Proceedings of the International Conference, Oxford, UK, 29-30 September 1994; Barker, D.H., Telford, T., Eds.; American Society of Civil Engineers [Distributor]: London, UK; New York, NY, USA, 1995; pp. 2-25. ISBN 0727720317.

64. Vannoppen, W.; Vanmaercke, M.; de Baets, S.; Poesen, J. A review of the mechanical effects of plant roots on concentrated flow erosion rates. Earth Sci. Rev. 2015, 150, 666-678. [CrossRef]

65. Gyssels, G.; Poesen, J.; Bochet, E.; Li, Y. Impact of plant roots on the resistance of soils to erosion by water: A review. Prog. Phys. Geogr. 2005, 29, 189-217. [CrossRef]

66. Technical Advisory Committee for Flood Defence (TAW). Erosion Resistance of Grassland as Dike Covering; Technical Report; TAW: Delft, The Netherlands, 1997.

67. Hiller, H. Über das Schutzvermögen der Grasnarben auf einigen Seedeichen in Ostfriesland. Zeitschrift für Kulturtechnik und Flurbereinigung 1973, 14, 99-111.

68. Hiller, H. Der biotechnische Wert von standortgemäßen Grasnarben auf Flußdeichen-Ansaatmischungen, Anlage und Pflege. In Ingenieurbiologie_Flußdeiche und Flußdämme, Bewuchs und Standsicherheit; Pflug, W., Hacker, E., Eds.; Selbstverlag der Gesellschaft für Ingenieurbiologie: Aachen, Germany, 1999; pp. 119-152. ISBN 3-9802634-4-4.

69. Jittler, M. Struktur- und Standortanalysen der Vegetation von Landesschutzdeichen im Elbeästuar; Eine Analyse vor dem Hintergrund der Deichsicherheit; Kovač: Hamburg, Germany, 2001; ISBN 978-3-8300-0416-5.

70. Pohl, C.; Richwien, W. Die Bemessung der Außenböschung von Seedeichen unter Ansatz des festigkeitssteigernden Einflusses der Grasnarbe In Sicherung von Dämmen, Deichen und Stauanlagen: Handbuch für Theorie und Praxis Vol. II; Herrmann, R.A., Jensen, J., Eds.; Universitätsverlag Siegen: Siegen, Germany, 2006; pp. 55-76.

71. Pilarczyk, K.W. Dikes and Revetments. Design, Maintenance and Safety Assessment; Routledge: London, UK, 2017; ISBN 1351454935.

72. Truong, P.; Gordon, I.; Armstrong, F. Vetiver Grass for Saline Land Rehabilitation under Tropical and Mediterranean Climate. In PUR\$L: Wake Up Australia! Saltland Opportunities: Profit for Our Communities and the Environment, Proceedings of the 8th National Conference and Workshop on the Productive Use and Rehabilitation of Saline Lands, Albany, Australia, 16-20 September 2002; Promaco Conventions: Perth, Australia, 2002; ISBN 9781863081016.

73. Islam, M.S.; Shahriar, B.A.M.; Parshi, F.N. Bio-Technical Solution for Dyke Protection in Saline Zone of Bangladesh. In Proceedings of the 2014 World Congress on Advances in Civil, Environmental, and Materials Research (ACEM14), Busan, Korea, 24-28 August 2014.

74. Möller, J.; Weissmann, R.; Schüttrumpf, H.; Kudella, M.; Oumeraci, H.; Richwien, W.; Grüne, J. Interaction of Wave Overtopping and Clay Properties for Seadikes. In Proceedings of the 28th International Conference on Coastal Engineering (ICCE 2002), Cardiff, UK, 7-12 July 2002.

75. Piontkowitz, T. EroGRASS: Failure of Grass Cover Layers at Seaward and Shoreward Dike Slopes. Performance, Results and Conclusions. 2012. Available online: http://www.masterpiece.dk/UploadetFiles/ 10852/36/EroGrassreportB.pdf (accessed on 2 August 2019).

76. Van der Meer, J.; Schrijver, R.; Hardeman, B.; van Hoven, A.; Verheij, H.; Steendam, G.J. Guidance on Erosion Resistance of Inner Slopes of Dikes from Three Years of Testing with the Wave Overtopping Simulator. In Coasts, Marine Structures and Breakwaters: Adapting to Change; Allsop, W., Ed.; Thomas Telford Ltd.: London, UK, 2010; pp. 460-473. ISBN 0-7277-4159-4.

77. Steendam, G.J.; van der Meer, J.W.; Hardeman, B.; van Hoven, A. Destructive wave overtopping tests on grass covered landward slopes of dikes and transitions to berms. Coast. Eng. Proc. 2010, 11, 8. [CrossRef]

78. Trung, L.H. Overtopping on Grass Covered Dikes: Resistance and Failure of the Inner Slopes. Ph.D. Thesis, Technische Universiteit Delft, Delft, The Netherlands, 2014.

79. Van Damme, M.; Ponsioen, L.; Herrero, M.; Peeters, P.; Lang, M.; Klijn, F.; Samuels, P. Comparing Overflow and Wave-Overtopping Induced Breach Initiation Mechanisms in an Embankment Breach Experiment. In Proceedings of the FLOODrisk 2016-3rd European Conference on Flood Risk Management, Lyon, France, 17-21 October 2016. [CrossRef]

80. Cantré, S.; Olschewski, J.; Saathoff, F. Full-scale flume experiments to analyze the surface erosion resistance of dike embankments made of dredged materials. J. Waterw. Port Coast. Ocean Eng. 2017, 143, 04017001. [CrossRef] 
81. Thornton, C.; Hughes, S.; Scholl, B. Full-Scale Testing of Levee Resiliency During Wave Overtopping. In Proceedings of the 6th International Conference on Scour and Erosion, Paris, France, 27-31 August 2012; pp. 1215-1222.

82. Thornton, C.; Hughes, S.; Scholl, B.; Youngblood, N. Estimating grass slope resiliency during wave overtopping: Results from full-scale overtopping simulator testing. Int. Conf. Coast. Eng. 2014, 1, 52. [CrossRef]

83. Van der Meer, J.W.; Allsop, N.W.H.; Bruce, T.; de Rouck, J.; Kortenhaus, A.; Pullen, T.; Schüttrumpf, H.; Troch, P.; Zanuttigh, B. EurOtop: Manual on Wave Overtopping of Sea Defences and Related Structures: An Overtopping Manual Largely Based on European Research, But for Worldwide Application. 2018. Available online: www.overtopping-manual.com (accessed on 2 August 2019).

84. Van Steeg, P.; Klein Breteler, M.; Labrujere, A. Use of wave impact generator and wave flume to determine strength of outer slopes of grass dikes under wave loads. Coast. Eng. Proc. 2015, 1, 60. [CrossRef]

85. Führböter, A. Der Druckschlag durch Brecher auf Deichböschungen. In Mitteilungen des Franzius-Instituts für Grund- und Wasserbau der Technischen Universität Hannover; Franzius-Institut der TU Hannover: Hannover, Germany, 1966.

86. Sprangers, H. Vegetation Dynamics and Erosion Resistance of Sea Dyke Grassland. Ph.D. Thesis, Wageningen Agricultural University, Wageningen, The Netherlands, 1999.

87. Berendse, F.; van Ruijven, J.; Jongejans, E.; Keesstra, S. Loss of plant species diversity reduces soil erosion resistance. Ecosystems 2015, 18, 881-888. [CrossRef]

88. Haselsteiner, R. Der Bewuchs an und auf Hochwasserschutzdeichen an Fließgewässern aus technischer und naturschutzfachlicher Sicht. In Wasserbau und Umwelt - Anforderungen, Methoden, Lösungen. Dresdner Wasserbauliche Mitteilungen 40; Technische Universität Dresden, Institut für Wasserbau und technische Hydromechanik: Dresden, Germany, 2010; pp. 373-382.

89. Zanetti, C.; Macia, J.; Liency, N.; Vennetier, M.; Mériaux, P.; Provansal, M.; Lang, M.; Klijn, F.; Samuels, P. Roles of the riparian vegetation: The antagonism between flooding risk and the protection of environments. E3S Web Conf. 2016, 7, 13015. [CrossRef]

90. DIN Deutsches Institut für Normung e.V. Hochwasserschutzanlagen an Fließgewässern; DIN 19712/2013; DIN Deutsches Institut für Normung e.V.: Berlin, Germany, 2013.

91. Haselsteiner, R. Woody Vegetation on Small Embankments. In Proceedings of the 8th ICOLD European Club Symposium: Dam Safety—Sustainability in a Changing Environment, Innsbruck, Austria, 22-23 September 2010.

92. Haselsteiner, R.; Strobl, T. Deichertüchtigung unter besonderer Berücksichtigung von Gehölzen. In Sicherung von Dämmen, Deichen und Stauanlagen: Handbuch für Theorie und Praxis Vol. II; Herrmann, R.A., Jensen, J., Eds.; Universitätsverlag Siegen: Siegen, Germany, 2006; pp. 325-353.

93. Deutsche Vereinigung für Wasserwirtschaft, Abwasser und Abfall e.V. Deiche an Fließgewässern Teil 1: Planung, Bau und Betrieb; DWA-M 507-1; Deutsche Vereinigung für Wasserwirtschaft, Abwasser und Abfall e.V.: Hennef, Germany, 2011.

94. Seethaler, L. Wurzelausbreitung von Gehölzen auf Flußdeichen. In Ingenieurbiologie—Flußdeiche und Flußdämme, Bewuchs und Standsicherheit; Pflug, W., Hacker, E., Eds.; Selbstverlag der Gesellschaft für Ingenieurbiologie: Aachen, Germany, 1999; pp. 215-232. ISBN 3-9802634-4-4.

95. Pflug, W.; Stähr, E. Wald auf und an Flussdeichen. In Ingenieurbiologie_Flußdeiche und Flußdämme, Bewuchs und Standsicherheit; Pflug, W., Hacker, E., Eds.; Selbstverlag der Gesellschaft für Ingenieurbiologie: Aachen, Germany, 1999; pp. 297-321. ISBN 3-9802634-4-4.

96. Zhang, J.; Nakamura, H. Effect of tree roots on soil erosion control at seadikes in the northern part of the Hang Zhou Bay, China. J. Jpn. Soc. Eros. Control Eng. 1998, 51, 5-12. [CrossRef]

97. Lammeranner, W.; Haselsteiner, R. Ingenieurbiologische Bauweisen an Hochwasserschutzdeichen. In Wasserbau und Umwelt - Anforderungen, Methoden, Lösungen. Dresdner Wasserbauliche Mitteilungen 40; Technische Universität Dresden, Institut für Wasserbau und technische Hydromechanik: Dresden, Germany, 2010; pp. 191-200.

98. Kisse, A.; Ellebracht, M. Bäume auf Deichen-Hochwasserschutz kontra ökologische Landschaftsplanung? In Sicherung von Dämmen, Deichen und Stauanlagen: Handbuch für Theorie und Praxis Vol. V; Herrmann, R.A., Jensen, J., Eds.; Universitätsverlag - universi: Siegen, Germany, 2015; pp. 189-201.

99. Haselsteiner, R.; Mett, M.; Strobl, T. Überströmungssicherung von Deichen mit Geokunststoffen. In Proceedings of the 5. Geokunststoff-Kolloquium, Bad Lauterberg, Germany, 25-25 January 2007. 
100. Werth, K.; Heerten, G. Zukünftige Deichregelquerschnitte-Einfach nur höher und breiter? In Vorsorgender und Nachsorgender Hochwasserschutz; Heimerl, S., Meyer, H., Eds.; Springer Fachmedien Wiesbaden: Wiesbaden, Germany, 2014; pp. 392-401. ISBN 978-3-658-03739-0.

101. Mitobe, Y.; Adityawan, M.B.; Roh, M.; Tanaka, H.; Otsushi, K.; Kurosawa, T. Experimental study on embankment reinforcement by steel sheet pile structure against tsunami overflow. Coast. Eng. J. 2016, 58, 1640018-1-1640018-18. [CrossRef]

102. Lengkeek, H.J.; Bruijn, E. Soil Nailing in Clay for Dike Reinforcement. In Proceedings of the 17th International Conference on Soil Mechanics and Geotechnical Engineering, Alexandria, Egypt, 5-9 October 2009; pp. 1586-1589.

103. Natoli, E.; Admiraal, B.; de Wit, D.; Yahyaoui, A.; de Vos, W.J. River embankment strengthening by non-metallic nails: Overview on a permanent soil nailing for flood protection. Innov. Infrastruct. Solut. 2017, 2, 344. [CrossRef]

104. Heerten, G. Geosynthetische Tondichtungsbahnen als mineralisches Dichtungselement im Wasserbau und Umweltschutz. BauPortal 2014, 12, 32-41.

105. Theisen, M.S. The role of geosynthetics in erosion and sediment control: An overview. Geotext. Geomembr. 1992, 11, 535-550. [CrossRef]

106. Van der Meer, J.W.; Bernadini, P.; Steendam, G.J.; Akkerman, G.J.; Hoffmanns, G.J.C.M. The wave overtopping simulator in action. Coast. Struct. 2007, 2, 645-656. [CrossRef]

107. Akkerman, G.J.; Bernardini, P.; van der Meer, J.; Verheij, H.; van Hoven, A. Field tests on sea defences subject to wave overtopping. Coast. Struct. 2007, 2, 657-668. [CrossRef]

108. Akkerman, G.J.; van Gerven, K.A.J.; Schaap, H.A.; van der Meer, J.W. Work Package 3-Development of Alternative Overtopping-Resistant Sea Defences. Phase 3: Wave Overtopping Erosion Tests at Groningen Sea Dyke. Final Report. 2007. Available online: https://repository.tudelft.nl/islandora/object/uuid:5a9665beca95-4e6a-80d7-60f0a4221db8/datastream/OBJ/download (accessed on 2 July 2019).

109. Propex. Pyramat ${ }^{\circledR}:$ Product Data Pyramat ${ }^{\circledR} 75$ HPTRM. Available online: http://propexglobal.com/Portals/ 0/Product\%20PDFs/Erosion\%20Control/Product\%20Data\%20Sheets/PYRAMAT\%2075\%20PDS.pdf (accessed on 1 July 2019).

110. Tensar. Specification Sheet-VMax ${ }^{\circledR} P 550^{\circledR}$ Turf Reinforcement Mat. Available online: https://nagreen.com/ sites/default/files/2017-03/EC_RMX_MPDS_VMP550_5.13.pdf (accessed on 1 July 2019).

111. ASTM. ASTM D 6460-12: Standard Test Method for Determination of Rolled Erosion Control Product (RECP) Performance in Protecting Earthen Channels from Stormwater-Induced Erosion; American Society for Testing and Materials: West Conshohocken, PA, USA, 2012.

112. Pan, Y.; Li, L.; Amini, F.; Kuang, C. Full-scale HPTRM-strengthened levee testing under combined wave and surge overtopping conditions: Overtopping hydraulics, shear stress, and erosion analysis. J. Coast. Res. 2013, 286, 182-200. [CrossRef]

113. Pan, Y.; Li, L.; Amini, F.; Kuang, C. Overtopping erosion and failure mechanism of earthen levee strengthened by vegetated HPTRM system. Ocean Eng. 2015, 96, 139-148. [CrossRef]

114. Meyer, N.; Emersleben, A. Mechanisches Verhalten von bewehrten Böden mit Geozellen. In Proceedings of the 9. Informations- und Vortragstagung über "Geokunststoffe in der Geotechnik", Munich, Germany, 16-17 February 2005; pp. 19-55.

115. Wu, K.J.; Austin, D.N. Three-dimensional polyethylene geocells for erosion control and channel linings. Geotext. Geomembr. 1992, 11, 611-620. [CrossRef]

116. Hewlett, H.W.M.; Boorman, L.A.; Bramley, L.A. Design of Reinforced Grass Waterways; Construction Industry Research and Information Association: London, UK, 1987; ISBN 9780860172857.

117. Allen, R.J.; Webb, B.M. Determination of Wave Transmission Coefficients for Oyster Shell Bag Breakwaters. In Coastal Engineering Practice (2011); Magoon, O.T., Noble, R.M., Treadwell, D.D., Kim, Y.C., Eds.; American Society of Civil Engineers: Reston, VA, USA, 2011; pp. 684-697. ISBN 9780784411902.

118. Miller, J.K.; Rella, A.; Williams, A.; Sproule, E. Living Shorelines Engineering Guidelines. Prepared for: New Jersey Department of Environmental Protection; 2015. Available online: https://www.nj.gov/dep/cmp/ docs/living-shorelines-engineering-guidelines-final.pdf (accessed on 2 July 2019).

119. Tuya, F.; Vila, F.; Bergasa, O.; Zarranz, M.; Espino, F.; Robaina, R.R. Artificial seagrass leaves shield transplanted seagrass seedlings and increase their survivorship. Aquat. Bot. 2017, 136, 31-34. [CrossRef] 
120. Paul, M.; Amos, C.L. Spatial and seasonal variation in wave attenuation over Zostera noltii. J. Geophys. Res. 2011, 116, 138. [CrossRef]

121. Vuik, V. Building Safety with Nature. Ph.D. Thesis, Delft University of Technology, Delft, The Netherlands, 2019.

122. Scheres, B.; Graunke, A.; Wrage-Mönnig, N.; Schüttrumpf, H. Full-Scale Model Tests on the Erosion Resistance of Ecologically Valuable Sea Dike Vegetation. In Proceedings of the 9th Chinese-German Joint Symposium on Hydraulic and Ocean Engineering, Tainan, Taiwan, 11-17 November 2018; pp. 329-337.

123. Naylor, L.A.; Coombes, M.A.; Venn, O.; Roast, S.D.; Thompson, R.C. Facilitating ecological enhancement of coastal infrastructure: The role of policy, people and planning. Environ. Sci. Policy 2012, 22, 36-46. [CrossRef]

124. Nesshöver, C.; Assmuth, T.; Irvine, K.N.; Rusch, G.M.; Waylen, K.A.; Delbaere, B.; Haase, D.; Jones-Walters, L.; Keune, H.; Kovacs, E.; et al. The science, policy and practice of nature-based solutions: An interdisciplinary perspective. Sci. Total Environ. 2017, 579, 1215-1227. [CrossRef]

125. McNie, E.C. Reconciling the supply of scientific information with user demands: An analysis of the problem and review of the literature. Environ. Sci. Policy 2007, 10, 17-38. [CrossRef]

126. Benda, L.E.E.E.; Poff, N.L.; Tague, C.; Palmer, M.A.; Pizzuto, J.; Cooper, S.; Stanley, E.; Moglen, G. How to avoid train wrecks when using science in environmental problem solving. BioScience 2002, 52, 1127. [CrossRef]

127. Cundill, G.; Rodela, R. A review of assertions about the processes and outcomes of social learning in natural resource management. J. Environ. Manag. 2012, 113, 7-14. [CrossRef]

128. Basco-Carrera, L.; Warren, A.; van Beek, E.; Jonoski, A.; Giardino, A. Collaborative modelling or participatory modelling? A framework for water resources management. Environ. Model. Softw. 2017, 91, 95-110. [CrossRef]

129. Morris, R.L.; Konlechner, T.M.; Ghisalberti, M.; Swearer, S.E. From grey to green: Efficacy of eco-engineering solutions for nature-based coastal defence. Glob. Chang. Biol. 2018, 24, 1827-1842. [CrossRef]

130. Nobre, A.M. Scientific approaches to address challenges in coastal management. Mar. Ecol. Prog. Ser. 2011, 434, 279-289. [CrossRef]

(C) 2019 by the authors. Licensee MDPI, Basel, Switzerland. This article is an open access article distributed under the terms and conditions of the Creative Commons Attribution (CC BY) license (http://creativecommons.org/licenses/by/4.0/). 